\title{
Factors contributing to guilty plea wrongful convictions: A quantitative analysis of
}

\section{Australian appellate court judgements}

\author{
Ms. Caitlin Nash ${ }^{1}$ \\ Dr. Rachel Dioso-Villa ${ }^{1}$ \\ Dr. Louise Porter ${ }^{1}$ \\ ${ }^{1}$ School of Criminology and Criminal Justice, Griffith Criminology Institute \\ Griffith University. Brisbane, Australia
}

\begin{abstract}
Criminal defendants can face significant pressures to plead guilty, but wrongful conviction scholarship has largely overlooked the study of guilty pleas. This study content analysed 139 Australian appellate court judgements in which a guilty plea conviction was overturned, investigating the types of errors involved in these convictions, and the stage of the criminal justice process at which the errors occurred. The findings revealed that errors occurred during the police investigation, pretrial preparations and formal court procedures, with the most frequent errors involving incorrect or inappropriate charges, inadequate legal representation, and the courts erroneously accepting a guilty plea. The findings raise important implications regarding the adequacy of safeguards to ensure guilty pleas are appropriate or factually and legally accurate.
\end{abstract}

Keywords: Wrongful convictions, miscarriage of justice, guilty pleas, false guilty pleas, system error, erroneous convictions 
There is increasing recognition that innocent persons are pleading guilty to crimes they did not commit. This issue has been most extensively documented in the United States, where the National Registry of Exonerations has documented 583 exonerees that were convicted by a guilty plea, representing $21 \%$ of all national exonerees documented as of July 2021. There is also growing evidence of guilty plea wrongful convictions in Canada, with six of the 23 innocent defendants exonerated by Innocence Canada being convicted by a guilty plea, while in England and Wales, approximately 50 of the 128 cases referred to the Court of Appeal by the Criminal Cases Review Commission as potential miscarriages of justice since 2012 involved defendants who initially pleaded guilty (Helm, 2019).

Despite their known occurrence, little empirical research has examined wrongful convictions following a guilty plea. Instead, most of our knowledge on wrongful convictions is based upon cases that followed a contested trial. This does not reflect contemporary criminal justice systems where the majority of cases are resolved by the defendant pleading guilty. For example, guilty pleas account for over $97 \%$ of all federal criminal convictions in the United States (United States Sentencing Commission, 2021), 74\% of all Crown Court cases in the United Kingdom (Ministry of Justice, 2021), and up to 70\% of all adjudicated criminal cases in Australia (Australian Bureau of Statistics, 2014). Whilst guilty pleas are mainly a feature of an adversarial system, a number of inquisitorial criminal justice systems have also implemented procedures for plea negotiations in response to pressure for greater efficiency $^{1}$ (Gilliéron, 2003). Given the lack of procedural protections associated with a guilty plea and their prevalence within the system, it has been argued that wrongful convictions based upon a guilty plea are likely to be much higher than those based upon a trial (Redlich, 2010).

While legal and psychological scholars have begun to examine reasons why innocent defendants may plead guilty (Redlich, 2010; Redlich et al., 2017; Sherrin, 2011), the extant 
literature does not provide an understanding as to how a guilty plea wrongful conviction may occur within the criminal justice system. This study addresses this gap in the literature by collecting and analysing Australian appellate court judgements where a guilty plea conviction was overturned on appeal, examining the types of errors that contributed to these convictions. Guided by a systems perspective, this paper pays particular attention to the stage of the criminal justice process in which the errors were made. This approach aims to provide a greater understanding of how a guilty plea wrongful conviction can occur, and to highlight possibilities for preventing or reducing their occurrence.

\section{Defining Wrongful Conviction}

It is important to first define a 'wrongful conviction'. The term wrongful conviction has become largely associated with the conviction of 'factually innocent' persons who did not commit the crime (Hughes, 2011). However, wrongful convictions can also describe persons who are legally innocent, in which they had a legally relevant defence that should have resulted in an acquittal (Parkes \& Cunliffe, 2015), or were unfairly convicted based on procedural or legal errors that would inform a successful appeal (Roberts \& Weathered, 2009). In recent years, scholars have come to criticise the predominate focus on 'factual innocence' in wrongful conviction scholarship, arguing that it devalues other forms of innocence and the values of procedural justice (Hughes, 2011; Raymond, 2001).

This study adopts a broad definition of wrongful convictions and includes all cases in which a guilty plea conviction was set aside on appeal, regardless of whether this was a result of factual, legal, or procedural error. This more encompassing definition is particularly important when examining guilty plea convictions, as defendants who plead guilty can waive many procedural protections associated with a trial, such as the presumption of innocence and the requirement for the prosecution to prove the case beyond a reasonable doubt. As most defendants plead guilty, it is critically important to ensure that these convictions are achieved 
through fair and just procedures, and that these convictions are appropriate, not just factually accurate.

\section{Factors Contributing to False Guilty Pleas}

There has been growing recognition that criminal defendants can face significant pressures to plead guilty, regardless of their guilt or innocence. This literature has largely focused on the impact of plea-bargaining, where a number of scholars have raised concerns that innocent persons are pleading guilty to receive the more lenient sentence that is associated with a plea (Blume \& Helm, 2014; Bowers, 2008; Sherrin, 2011). This issue is particularly apparent in the United States, where large discrepancies between the likely sentence received at trial compared to the sentence offered in a plea bargain has been shown to unduly compel innocent persons to plead guilty to crimes they did not commit (Covey, 2013; Dervan \& Edkins, 2013; Zottoli et al., 2016). While the practice of plea-bargaining is more restrictive in Australia, as prosecutions cannot guarantee sentences in exchange for a guilty plea, some scholars have raised concerns that prosecutors may be using their discretionary powers to 'overcharge' a defendant with multiple and/or more serious offences in order to unduly compel them into pleading guilty to a 'bargained' version of these charges (Flynn \& Fitz-Gibbon, 2011, p. 216).

Defence lawyers may also be putting pressures on defendants to plead guilty, with legal advice being shown to have a strong influence over an innocent defendant's decision to plead guilty (Henderson \& Levett, 2018; Malloy et al., 2014). Pressure to plead guilty is also argued to be greater for innocent persons accused of minor offences than serious crimes, as the financial, emotional and time costs associated with proceeding to trial can be perceived to outweigh the consequences of a guilty plea (Blume \& Helm, 2014; Bowers, 2008; Cheng, 2013; Sherrin, 2011). This is likely exacerbated for defendants held in pre-trial detention, with research finding that defendants who are denied bail are more likely to plead guilty 
simply to get out of jail (Edkins \& Dervan, 2018; Kellough \& Wortley, 2002). Research on false guilty pleas also suggests that certain vulnerable populations may be more likely to plead guilty when innocent, such as juvenile defendants (Redlich \& Shteynberg, 2016), Indigenous persons (Carling, 2017; Roach, 2015), or those with mental health issues or cognitive impairments (Redlich et al., 2010). Due to their vulnerabilities, these accused persons are likely to face greater pressures to plead guilty without being sufficiently aware of the implications of a guilty plea.

\section{Contributing Causes of Wrongful Convictions}

While there is growing recognition that innocent persons can face significant pressures to plead guilty, this issue has been largely overlooked within wrongful conviction scholarship. Studies in the U.S. have generated an extensive dataset of wrongful convictions from which several contributing factors have been identified, including eyewitness misidentifications, false confessions, perjury or false accusation, false or misleading forensic evidence, official misconduct and incompetent counsel (Garrett, 2011; Gross \& Shaffer, 2012; Huff et al., 1986). While care should be taken before applying these same factors to other systems, research suggests that similar issues are also apparent in Australia (DiosoVilla, 2015), Canada (Roach, 2011), and the United Kingdom (Walker \& McCartney, 2008). However, the vast majority of this research is based upon cases that followed a contested trial, and mostly involves convictions for more serious offences of rape and murder that have long prison sentences (Gross, 2017). As a result, relatively little is known regarding the contributing causes of wrongful convictions that follow a guilty plea, particularly for defendants who may be falsely pleading guilty to minor offences.

\section{A Systems Perspective}

The current study examines guilty plea wrongful convictions from a systems 
perspective. This views the criminal justice system as an organisational system consisting of interrelated, interacting and independent parts (Doyle, 2010; Luna, 2005). This approach acknowledges that wrongful convictions are not the result of individual or discrete errors, but rather are complex events in which small mistakes combine with each other and with underlying system weaknesses to create a system failure (Doyle, 2010). As observed by Colvin (2009) " [w]rongful accusations do not necessarily lead to wrongful convictions. They lead to wrongful convictions when the safeguards of the criminal justice system fail" (p. 174). Applying this perspective to guilty plea wrongful convictions, it can be argued that, while innocent defendants may face substantial pressures to plead guilty, a more systematic approach is needed to determine how a defendant is able to falsely plead guilty and receive a criminal conviction without the intervention of numerous criminal justice actors involved in the process. This study adopts a systems perspective to examine guilty plea wrongful convictions by viewing the potential for error during each stage of the criminal justice process, from the police investigation to pretrial preparations and formal court procedures. It is hoped that studying what, and where, errors occur in the different stages of the criminal justice process will provide a more comprehensive understanding of how guilty plea wrongful convictions can occur.

\section{Method}

\section{Data}

The data used in this study were Australian appellate court judgements where a conviction based upon a guilty plea was set aside on appeal ${ }^{2}$. The broad definition of wrongful convictions included all cases in which a guilty plea conviction was set aside on appeal, regardless of whether this was a result of factual, legal, or procedural error. This approach removed the need for subjective judgements about case selection. Moreover, in Australia, an accused person can only have a guilty plea conviction set aside if they can 
demonstrate that a 'miscarriage of justice' has occurred (Meissner $v R, 1995)$, which already provides a strict definition for which cases can be considered.

Persons who wish to appeal a guilty plea conviction must request for the conviction to be reviewed by a higher court. Persons who plead guilty in the Magistrate Court apply for an appeal against their conviction to be heard in the District or Supreme Court ${ }^{3}$, while persons who plead guilty in the District or Supreme Court apply to have their appeal heard in the Court of Appeal. Reported and unreported judgements of these court proceedings are made available in online legal databases. These judgements provide a summary of the case, the arguments presented by the parties as to why the conviction should or should not be set aside, and the reasons provided by the court as to why the conviction was overturned.

Relevant cases were located from the legal databases LexisNexis and AustLII by using the search terms 'guilty plea', 'plead guilty', 'miscarriage of justice' and 'set aside'. This returned a search result of 1,256 cases. Each case was quickly reviewed to determine relevance, excluding all cases that did not involve a person successfully appealing a guilty plea conviction. This excluded cases where the defendant appealed only the sentence received, not the conviction, as well as cases in which the defendant appealed to have their guilty plea withdrawn or changed prior to conviction, as these defendants had not yet been convicted. All cases in which an appellant had their guilty plea conviction set aside on appeal were included in the study, resulting in a sample size of 139 cases.

\section{Sample}

All Australian states and territories are represented in the data. Most cases occurred in Western Australia (34\%), followed by New South Wales (16.5\%), Queensland (15\%), South Australia (15\%), Victoria (10\%), the Australian Capital Territory (5\%), the Northern Territory (3\%) and Tasmania (1.5\%). The date of the judgements ranged from 1966 to 2020, with the majority $(78 \%)$ occurring after $2001(M=2007, S D=10.101)$. The majority of the 
defendants were convicted in the Magistrates Court (57\%), while 37\% were convicted in the District Court, $6 \%$ in the Supreme Court, and 1\% were convicted in the Children's Court. The defendants pleaded guilty to a range of offences; the most serious of each conviction overturned on appeal is presented in Table 1 . The majority of the wrongfully convicted defendants were male (83.5\%). At least $6.5 \%$ of the cases involved Indigenous Australians, while 9\% involved persons from another cultural or linguistic background that was not Anglo-Australian or Aboriginal or Torres Strait Islander. Whether the defendant had legal representation at the time of pleading guilty was known in 116 cases, with almost two thirds $(65 \%)$ of these being legally represented, while $35 \%$ were self-represented.

\section{[TABLE 1 HERE]}

\section{Data Coding and Analytic Strategy}

The data were content analysed for the types of errors that contributed to the guilty plea wrongful conviction, and the stage of the criminal justice process the error occurred. Cases were initially analysed using codes based upon previous literature on factors that are believed to contribute to wrongful convictions and false guilty pleas (Dioso-Villa, 2015; Gross \& Shaffer, 2012; Sherrin, 2011). Within the course of analysis, these codes where then modified and additional codes added based upon the primary data, allowing new categories to emerge inductively (Zhang \& Wildemuth, 2017). As this study adopted a broad definition of wrongful conviction, each case was also categorised by type of wrongful conviction, distinguishing between convictions overturned on the basis of factual, legal or procedural error. The case and defendant characteristics of each case were also recorded, such as the defendants' gender, the crimes they pleaded guilty to, and the original court the defendant was convicted $\mathrm{in}^{4}$. In total, 30 variables were extracted from the data. The full coding dictionary outlining the variables and their definitions can be found in the Appendix.

All 139 cases were coded by the first author using the developed coding dictionary. 
The types of errors contributing to guilty plea wrongful convictions and the stage in which they occurred were not mutually exclusive; cases could involve more than one error committed at more than one stage of the process. These were therefore coded dichotomously as to whether or not each was present in a given case $(1=$ present, $0=$ not present $)$. Errors were only recorded if they were identified as a contributing factor to the wrongful conviction by the appellate court. This was to ensure objectivity and to avoid making subjective inferences of what 'caused' the wrongful conviction. Similarly, when coding for the type of wrongful conviction, the categories were distinguished based upon the reasons given by the appellate court as to why the conviction was overturned. These variables were mutually exclusive; a case could only represent one type of wrongful conviction.

The data were primarily analysed descriptively, examining the frequencies of the variables recorded within the dataset to show the range and prevalence of errors, and stages at which they occurred. However, since this study adopted a broad definition of wrongful conviction, while most wrongful conviction scholarship focuses upon factual innocence, chisquare tests were conducted to determine whether any significant differences existed across the types of wrongful convictions with respect to the types of errors and the stage of the process the errors occurred. Where expected frequencies were less than five, Fisher's exact test was employed to test for significance. Adjusted standardised residuals were examined to identify the cells contributing to significance (residuals exceeding +/- 1.96).

\section{Findings}

Table 2 shows the case-level frequencies of error that contributed to the guilty plea wrongful convictions, and the stage of the process the errors occurred (i.e., the proportion of the 139 cases that involved the errors and stages). Cases most frequently involved the court erroneously accepting a guilty plea (33\%), charging errors (29\%), and inadequate defence representation (28\%). In two (1\%) cases, the accused falsely pleaded guilty based upon their 
own free choice and knowledge of the consequences, with no identifiable error within the criminal justice system contributing to the wrongful conviction ${ }^{5}$. The majority $(70 \%)$ of cases involved errors that occurred during pretrial preparations, followed by formal court proceedings (54\%), while only $8 \%$ of cases had errors occurring during the police investigation. In total, the cases involved 216 separate errors. Figure 1 shows the error-level frequencies; that is, how often each type of error occurred in the different stages of the criminal justice process. The frequency patterns of errors at each stage are described below.

[TABLE 2 HERE]

[FIGURE 1 HERE]

\section{The Police Investigation}

In total, $8 \%(n=17)$ of all errors were made during the police investigation process. These mostly involved errors in the collection and analysis of evidence, resulting in the police identifying and arresting the wrong person (who did not commit the crime). This included cases where witnesses or the victim mistakenly or falsely identified the defendant as the perpetrator of the crime, the accused person falsely confessed to the crime, or forensic evidence falsely incriminated the accused person as the perpetrator of a crime ${ }^{6}$. In four $(3 \%)$ cases, the wrongful conviction was the result of an inadequate police investigation. This mostly involved charging defendants despite available evidence demonstrating they were not guilty of the offence, while one case involved poor police practices that raised concerns as to the validity of the evidence gathered. Four (3\%) cases involved overt police misconduct, committed during the police investigation and/or pretrial stage. Misconduct during the police investigation included coercing confessions through verbal threats or physical acts of violence, excessive use of force, and laying false charges, while misconduct during pretrial preparations included the police prosecution making false statements or the police exaggerating a defendant's criminal history to deny them bail. 


\section{Pretrial Preparations}

Pretrial preparation refers to the prosecution process following the arrest or summons of a defendant. This category captures errors that occurred during informal pretrial procedures that occurred outside of the courtroom, with no judicial oversight or involvement. Half $(50.5 \% ; n=109)$ of all errors were made during this stage of the process, and mostly involved the defendant being incorrectly or inappropriately charged, receiving inadequate legal representation, or not having the legal knowledge, mental capability, or linguistic understanding to make an informed and appropriate plea decision. These are discussed in detail below, but it should be noted that errors associated with official misconduct and undue pressure also occurred at this stage, but with lower frequency (see Figure 1).

\section{Charging Errors}

Nearly a third $(29 \% ; n=40)$ of the cases involved charging errors at the pre-trial stage, in which incorrect or inappropriate charges laid by the prosecution contributed to the guilty plea wrongful conviction. The majority of these involved the defendant being incorrectly charged with the 'wrong' offence, in which the facts of the case did not fulfill the elements of the charge/s laid, and the defendant was convicted of a crime they legally did not commit. It also included cases in which the defendant was inappropriately charged with more offences than they committed, resulting in double punishment, or cases in which charges were not properly presented or particularised.

A typical example of a charging error is illustrated in the case of Nelson $v$ Haynes (2003), where the defendant was convicted of storing pornographic material on his work computer after receiving an unsolicited email. He pleaded guilty to using a computer service to obtain possession of an article, knowing it to be objectionable material, and was fined $\$ 1,000$. However, the admitted facts of the case did not constitute the offence of which the 
applicant was convicted, as it was accepted that the defendant did not know it to be objectional material at the time. The Western Australia Court of Appeal therefore set aside the defendant's conviction, finding that the defendant had "been convicted of an offence of which he was not guilty" (Nelson v Haynes, 2003, para. 65).

\section{Inadequate Defence Representation}

Inadequate defence representation at the pretrial stage contributed to the guilty plea wrongful conviction in one-quarter $(n=35)$ of the cases. This most often involved the defendant pleading guilty on the basis of insufficient or erroneous legal advice. In these cases, a defence lawyer either incorrectly informed the defendant that they were guilty of the charge, or they failed to adequately explain the charges against the defendant, to consider or explain relevant defences, or to adequately explain the processes of the court. For example, in $R v$ Williamson (2012), the female defendant pleaded guilty to torture in relation to her alleged treatment of a foster child. However, she did not understand that her guilty plea meant that she intentionally inflicted severe pain and suffering on the child. The Queensland Court of Appeal found that Williamson's misapprehension was due to incompetent legal advice from her solicitors, who failed to explain in straightforward language the nature of the charge, the effect of the plea, and the court process ( $R v$ Williamson, 2012).

Three cases (2\%) also involved inadequate defence representation during formal court proceedings, in which the defence failed to adequately challenge the prosecution's case or to provide a vigorous defence. For example, in $R v$ Wilkes (2001), an Indigenous defendant pleaded guilty during his murder trial based upon legal advice that it was "virtually certain" that he would be found guilty on the basis of eyewitness evidence (para. 23). However, his counsel conceded that he could have cross-examined witnesses on various aspects of their evidence, and the New South Wales Court of Appeal concluded that several issues could have been further explored or tested ( $R v$ Wilkes, 2001). 


\section{Legal Misunderstandings}

Fifteen per cent $(n=21)$ of cases involved a guilty plea from a defendant that had a poor or mistaken understanding of the law and the legal process. In $18(13 \%)$ cases, the defendant did not have their legal misunderstandings addressed before proceeding to court, and they entered a guilty plea without fully understanding the charges against them, were unaware they had an arguable defence to the charge, or they lacked a general understanding of the implications of a guilty plea. For instance, in Vulin v Kirkman (2012), the female defendant entered a plea of guilty for possessing an oleoresin capsicum spray on the "basis of a material misunderstanding of the law" (para. 47), as she was unaware that possessing a weapon for her own protection presented a defence to the charge. In three (2\%) cases, the defendant initially pleaded not guilty and intended to contest the charge, but became confused during formal court proceedings and changed their plea to guilty. Interestingly, $71 \%(n=15)$ of the 21 cases featuring legal misunderstandings involved a self-represented defendant ${ }^{7}$.

\section{Mental Incompetence}

Ten per cent $(n=14)$ of cases involved a guilty plea from a mentally incompetent defendant who was unable to make a free and informed decision to plead guilty. This involved mentally ill or cognitively impaired defendants who were either unfit to plead guilty, were not of sound mind at the time of committing the offence or entering the plea, or lacked the capacity to fully understand the charges against them and the implications of their guilty plea. In half $(n=7)$ of these cases, the appellate court placed responsibility on the defendant's legal representation for not recognising or addressing the defendant's mental impairment during pretrial procedures, while in the other half $(n=7)$ of the cases, the appellate court placed this responsibility on the judge during formal court procedures. In five of the cases featuring mental incompetence, the person's mental impairment was recognised 
before they entered the guilty plea, but they did not receive the support or assistance required to make an informed plea and no mental health assessment was conducted. However, in nine cases, the defendant's mental vulnerability was recognised only after they had pleaded guilty and were convicted.

\section{Language Difficulties}

A total of nine instances of language difficulties were identified across the cases, occurring in the police investigation $(n=1)$, pretrial preparations $(n=4)$ as well as formal court procedures $(n=4)$. Language difficulties contributed to seven $(5 \%)$ wrongful convictions and involved linguistic or translation issues for accused persons where English was not their first language. This included the police interviewing a defendant without an interpreter present, defence lawyers struggling to effectively communicate with the defendant pretrial, and the defendant not understanding formal court proceedings, resulting in an uninformed and misunderstood guilty plea.

\section{Formal Court Procedures}

In total, $42 \%(\mathrm{n}=90)$ of all errors were made during formal court proceedings, including court hearings conducted before a case proceeded to trial, after a case had proceeded to trial, or during a sentencing hearing. These errors mostly involved the prosecution or defence submitting false or misleading statements to court, judicial officers exerting undue pressure on defendants to plead guilty, and the court erroneously accepting a plea and recording a conviction. Errors associated with forensic evidence, inadequate defence representation, and legal misunderstandings also occurred at this stage, but with lower frequency, while mental incompetence and language difficulties occurred equally across both pretrial preparations (discussed above) and formal court procedures (see Figure 1).

\section{Misleading Submissions}


Five per cent $(n=7)$ of cases involved false or misleading submissions, all occurring during formal court proceedings. This included cases where the defence or prosecution unintentionally presented incorrect facts or laws of the case, leading the court into error. Three of these cases involved the prosecutor or defence lawyer misinterpreting the law and erroneously stating that the defendant's actions constituted the alleged offence, while four involved the prosecution unintentionally presenting false facts of the case.

\section{Undue Pressure}

While undue pressure was also identified to have been exerted by a police officer during a police interview $(\mathrm{n}=1)$ and by the prosecution during plea-negotiations pretrial $(\mathrm{n}=$ 2), this study found that undue pressure was most often exerted by judicial officers during formal court proceedings ( $n=9 ; 6 \%$ of all cases). This included three cases in which judicial officers were found to have unduly influenced a defendant's decision to plead guilty by expressing their opinion on the strength of the case and likelihood of conviction, while two cases involved magistrates putting pressure on defendants to change their plea of not guilty to guilty during a court hearing. In another three cases, magistrates put undue pressure on defendants to plead guilty through the threat of remand, giving them the option to either plead guilty and avoid or be released from custody, or plead not guilty and be sent to jail.

\section{Erroneous Acceptance of a Plea}

One third $(33 \% ; \mathrm{n}=46)$ of the cases involved erroneous acceptance of a plea, where the appellate court found that the original court had erroneously accepted a guilty plea and recorded a conviction in circumstances in which it was inappropriate to do so. This included cases where the facts or laws of the case, as it was known by the court at the time of the plea, showed that the defendant was not guilty of the charged offence, had an arguable defence to the charge, or had pleaded guilty to inappropriate charges. It also included cases where the 
court failed to make the necessary inquiries of the accused person, such as ensuring the defendant understood the charges against them, had an opportunity to receive legal advice, or accepted a guilty plea in cases where evidence suggested the defendant was mentally unfit to be tried.

An example of an erroneous acceptance of a plea is illustrated in $R v G V(2006)$, where the defendant pleaded guilty to dangerous operation of a motor vehicle causing grievous bodily harm for speeding through a red light and colliding with another car, seriously injuring his passenger. In sentencing, the prosecution set out facts of the case which raised the defence of 'sudden or extraordinary emergency', as the young driver had been speeding to escape an aggressive group of 'skinheads' who had been shouting abuse, making threats, and throwing bottles at the car, pursuing the defendant and his passengers for more than 11 kilometres. The Queensland Court of Appeal found that the sentencing judge should not have accepted the plea of guilty, as the facts of the case raised an arguable defence to the charge, unfairly denying the defendant a fair opportunity of an acquittal $(R v G V, 2006)$.

\section{Type of Wrongful Conviction}

The majority $(58 \% ; \mathrm{n}=81)$ of cases were legal wrongful convictions, where the conviction was overturned on the basis that the defendant may not have been legally culpable for the offence convicted. This included convictions of persons who had an arguable defence to the charge, were charged with a more serious offence than they committed, or their actions did not constitute the offence for which they were charged. Nearly a third $(30 \% ; n=42)$ were procedural wrongful convictions, where the guilty plea conviction was overturned on the basis of a procedural error. This included cases where the defendant was unfairly pressured to plead guilty, or they did not receive the support and assistance required to make an informed and appropriate plea decision. Twelve per cent $(n=16)$ of cases were factual wrongful 
convictions, where the conviction was overturned on the basis that the defendant may not have committed the crime and was factually innocent.

Table 3 shows comparisons of the different types of wrongful convictions by the types of errors involved and the stage in which the errors occurred. Chi-square analysis and examination of the adjusted standardised residuals showed that cases involving identification errors, false confessions, official misconduct, and errors made during the police investigation process were all significantly over-represented amongst factual wrongful convictions.

Charging errors, legal misunderstandings and errors made during pretrial preparations were significantly over-represented among legal wrongful convictions, while mental incompetence, undue pressure, erroneous acceptance of a plea and errors made during formal court hearing were significantly over-represented amongst procedural wrongful convictions. These findings suggest that different types of errors contribute to different categories of wrongful convictions.

\section{[TABLE 3 HERE]}

\section{Discussion}

Although most criminal cases are resolved by a guilty plea, there is limited research on wrongful convictions stemming from a guilty plea. This study provides an important contribution to the literature by analysing appellate court judgements in which a guilty plea conviction has been overturned on appeal, revealing the factors contributing to these erroneous convictions and at what stage in the process errors are likely to occur. Findings also revealed important differences between factual, legal and procedural guilty plea wrongful convictions.

The police investigation largely contributed to factual wrongful convictions, with mistakes or misconduct in the collection and analysis of evidence contributing to the identification and arrest of a factually innocent person who did not commit the crime. 
However, rather than proceeding to trial to contest their innocence, these cases were resolved by the defendant pleading guilty, with some acknowledging that they could not effectively challenge the evidence against them and pleading guilty to receive a lesser sentence. These findings align with guilty plea wrongful convictions documented in Canada (Roach, 2011) and the United States (Covey, 2013), and support concerns that innocent persons plead guilty when presented with what appears to be strong evidence in order to avoid risking a harsher penalty following a trial (Sherrin, 2011). The results also highlight the lack of safeguards in the plea process, as the errors or misconduct in the police investigation did not undergo any scrutiny or challenge and were, therefore, not identified and corrected (Redlich, 2010)

Errors during pretrial preparations were found to have largely contributed to legal wrongful convictions where the defendant may not have been legally culpable for the charge. This appeared to be mostly a result of a misapprehension or misinterpretation of the law from both the legal professionals and defendants involved in the cases. For instance, many of the wrongful convictions were the result of incorrect charges being laid, where the agreed facts of the case did not fulfill the elements of the offence. However, these charging errors were not identified or corrected by any of the parties involved, resulting in the defendant being wrongfully convicted of a crime they did not in law commit.

While previous scholars have raised concerns that prosecutors may be using their discretionary powers to 'overcharge' defendants in order to compel them into pleading guilty (Flynn \& Fitz-Gibbon, 2011), this was not apparent in the appellate court judgements. Instead, the findings support anecdotal reports from legal professionals that attribute erroneous charges to the inexperience and lack of legal training among the police, rather than a deliberate or malicious tactic of the prosecution (Flynn \& Freiberg, 2018). However, these charging errors were not recognised or corrected before the defendant pleaded guilty and was convicted, raising concerns regarding the adequacy of safeguards to ensure defendants are 
being convicted of appropriate charges. While prosecutors are expected to review cases and ensure the charges laid are appropriate, the majority of prosecutions in Australia are run by police prosecutors, who are not required to hold a legal qualification. As such, they may lack the legal knowledge required to ensure the charges laid by police are the correct legal charges applicable to a set of facts. Furthermore, police prosecutors deal with a high-volume workload, which may hinder their ability to thoroughly review a case before accepting a guilty plea (Yang, 2013). With nearly a third of the cases being overturned on the basis of erroneous charges, this suggests a need for additional legal training for both police and police prosecutors to ensure that the charges laid accurately and appropriately reflect the agreed facts of the case, and for increased attention and scrutiny of the charges laid before a guilty plea is accepted.

The findings also suggest that defendants are not receiving the support or assistance required to make an informed and knowledgeable plea decision. While legal representation is often recognised as an important safeguard, not all persons that appear before the courts have this benefit. In this study, nearly one third of defendants were self-represented, and they were more likely to enter a guilty plea without fully understanding the charges against them, the availability of potential defences, or the implications of a guilty plea. However, legal representation did not always ensure defendants received the legal advice and guidance needed. Instead, inadequate defence representation frequently contributed to the guilty plea wrongful conviction, supporting concerns that defendants may be receiving substandard legal advice over plea decisions (Sherrin, 2011).

The limitations on effective access to legal assistance may pose a particular problem for vulnerable suspects who may require additional support and assistance to make an appropriate and informed plea decision. While only a small proportion of cases in this study involved persons who were not mentally competent to plead guilty, the findings showed how 
they were processed through the criminal justice system without receiving the support and assistance required, or even having their vulnerabilities recognised. The Australian Human Right Commission (2014) found that persons with mental illness or intellectual disability are more likely to be 'pleaded out' by duty lawyers who do not have sufficient time available to identify the disability, concluding that systematic approaches to identify disabilities do not exist within the courts (p. 25). The current study findings reiterate the need for additional provisions for the assessment and identification of vulnerable defendants to ensure they receive the support and assistance required for effective access to justice. It is also recommended that accused persons presenting with such mental vulnerabilities have access to adequate legal representation that can assist them throughout the criminal justice process.

The results from this study also underscore the need for courts to recognise circumstances in which a defendant may be entering a guilty plea inappropriately. A third of the cases were overturned on the basis that the plea was erroneously accepted, suggesting that an important safeguard to ensure guilty pleas are appropriately entered is not being properly or consistently implemented. Instead, in many instances, the appellate court acknowledged that magistrate judges operate in a busy court and are under pressure to deal with cases speedily, which may hinder their ability to adequately fulfill their duties. As stated by Justice Layton in Nguyen v Police (2007) “...I bear in mind that Magistrates are under the pressure of a very heavy workload, and that [certain] precautions may occasionally be imperfectly observed when they are busily dispatching their business" (para. 21). This raises an important question of whether the judiciary can even provide a safeguard against an inappropriate guilty plea, as "expecting them to perform this task effectively in a busy court setting would be well-nigh impossible" (Peay \& Player, 2018, p. 951).

Due to a growing backlog of cases, courts are facing increasing pressures to quickly resolve cases and reduce court dockets. While this may hinder their ability to ensure guilty 
pleas are appropriately entered, the findings from this study also suggest that it may encourage judges to influence a defendant's decision to plead guilty. Previous Australian research has found that magistrates used a variety of strategies to encourage guilty pleas that maintained an image of judicial neutrality (Roach Anleu \& Mack, 2009). Similar findings were observed here, where judges influenced the decision to plead guilty by commenting on the strength of the case, encouraging the defendant to change their plea of not guilty during a court hearing, or by suggesting the defendant will avoid being held in pretrial detention. Research has shown that reducing caseloads allows judges to invest more time and resources in resolving a case (Engel \& Weinshall, 2020). Therefore, in order to allow magistrates to conduct their role effectively (and fairly), the findings from this study suggest a need to reduce the number of cases proceeding through the courts or to increase the number of magistrates and judicial staff that can manage the workload.

By adopting a more expansive definition of a wrongful conviction, this study differs from previous wrongful conviction scholarship that tends to focus solely on cases involving factual innocence. Comparing the different categories of wrongful convictions revealed that the definition influenced the types of errors involved, with factual, legal and procedural wrongful convictions involving different errors committed at different stages of the process. Factors associated with factual innocence identified in the current study are frequently cited causes of wrongful convictions in both international and Australian literature (Dioso-Villa, 2015; Garrett, 2011; Gross \& Shaffer, 2012), showing that these same factors are also apparent in wrongful convictions involving factually innocent persons who plead guilty. However, by adopting a broader definition, this study was able to capture a wider range of errors that may frequently occur in guilty plea convictions. It has been argued that the narrow focus on factual innocence "deflect[s] attention from unidentified miscarriages of justice" (Parkes \& Cunliffe, 2015, p. 219), and the current study highlights the benefits of adopting a 
more encompassing definition. By allowing a wider range of 'wrongs' to be recognised, this study provided a more comprehensive insight into erroneous guilty plea convictions, which can inform reform strategies to help prevent or reduce their occurrence.

The study of wrongful convictions is notoriously difficult, as they are an inherently hidden problem. By analysing appellate court judgements in which a guilty plea conviction was overturned on appeal, this study was able to identify relevant cases that had previously undergone legal scrutiny. However, it is acknowledged that convictions overturned on appeal do not represent the total number of wrongful convictions. Defendants can face numerous legal and practical difficulties in having their guilty plea conviction reviewed and overturned on appeal, and there are likely many erroneous guilty plea convictions that continue to go unrecognised. The lack of documented cases also creates difficulties in identifying and examining a comparison group, which could have identified systematic differences between guilty pleas that result in a wrongful conviction and those that escape conviction. For example, while persons can apply to have their guilty plea withdrawn or vacated before receiving a conviction, there are only a small number of cases in which this is successful. The study was also limited due to its reliance on the information provided in appellate court judgements for analysis. As appellate courts are generally limited to legal errors, they may not record information that may be relevant to this study, and the study may have overlooked some important factors that were not clearly identified or discussed. Lastly, the findings only highlight the immediate causes of wrongful convictions and do not reveal any underlying structural or 'root causes' that may contribute to these errors (Leo, 2005). To address these limitations, future research might build on these findings by interviewing criminal justice professionals that are directly involved in resolving cases through a guilty plea. This could capture additional errors and provide insight into the underlying structural or organisation features of the criminal justice system that may contribute to this issue. 


\section{Conclusion}

By analysing appellate court judgements in which a guilty plea conviction was overturned, this paper provided an important first step to understanding how guilty plea wrongful convictions may occur within the criminal justice system. The study shows a lack of adequate procedural protections and safeguards throughout the guilty plea process, allowing errors to proceed through the criminal justice system without being identified or corrected. Relying on defence lawyers and the courts to protect against inappropriate and uninformed guilty pleas is currently insufficient, suggesting a need for increased scrutiny and investigation of cases throughout each stage of the criminal justice process before a guilty plea is accepted. The findings also have important implications for post-conviction processes, as defendants can face significant difficulties in appealing a conviction based upon a guilty plea. Unlike our international counterparts, Australia has not implemented any significant governmental bodies or other legal mechanisms for the identification and correction of wrongful convictions, and there are limited options for errors to be discovered and corrected (Weathered, 2013). It is therefore recommended that Australia introduce a Criminal Cases Review Commission like those established in the United Kingdom and New Zealand, in which an independent body has the power to investigate claims of miscarriages of justice and to refer matters back to the Court of Appeal. This would allow for increased appellate access and ensure claims of wrongful convictions are systemically investigated, which is not guaranteed under the current mercy provisions available. With the criminal justice system's current reliance on resolving cases through a guilty plea and the constraints placed on appealing those convictions, there may be many more erroneous guilty pleas that remain hidden and uncorrected, with the wrongful convictions identified in this study likely representing the 'tip of the iceberg'. 


\section{Notes}

${ }^{1}$ Though guilty pleas may not exist in inquisitorial systems, research shows that false confessions (which also involve a false admission of guilt) are a contributing factor to wrongful convictions in both adversarial and inquisitorial criminal justice systems (Huff \& Killias, 2010).

${ }^{2}$ Whilst this study initially attempted to supplement the data with additional information from other sources, such as media reports, government documents, and other court documents, such supplementary materials were only available in a very small number of cases. Thus, the analysis was limited to the appellate court judgements, which provided the information necessary and ensured uniformity across the cases.

${ }^{3}$ In Queensland, the District Court will only allow an appeal against a guilty plea conviction if it finds that the plea of guilty was unequivocal (Hennessy v Vojvodic, 2010, para. 40). ${ }^{4}$ The defendants' characteristics were not always mentioned in the judgements, and variables measuring the defendant's age, criminal history and remand status were excluded due to missing data.

${ }^{5}$ This included one case where the defendant pleaded guilty because he mistakenly believed he was the perpetrator of the crime ( $R v$ Davies, 1993), while another involved a female defendant pleading guilty to protect her partner who was the real perpetrator of the crime (Lysaght v Youlden, 2018)

${ }^{6}$ One case involved forensic scientists mistakenly matching a DNA sample to the wrong person, while another involved preliminary testing of a powder falsely indicating the presence of illicit drugs.

${ }^{7}$ Of the cases that did involve legal representation, the appellate court did not find that the legal advice given by the defence lawyers in these cases was insufficient or erroneous. 


\section{References}

Australian Bureau of Statistics. (2014). Criminal courts, Australia, 2012-13 (Cat No. 4513.0). https://www.abs.gov.au/ausstats/abs@.nsf/Lookup/by\%20Subject/4513.0 201213 Main $\% 20$ Features $\sim$ Method $\% 20$ of $\% 20$ finalisation $\sim 13$

The Australian Human Right Commission. (2014). Equal before the law: Towards disability justice strategies. https://humanrights.gov.au/our-work/disabilityrights/publications/equal-law

Blume, J. H., \& Helm, R. K. (2014). The unexonerated: Factually innocent defendants who plead guilty. Cornell Law Review, 100(1), 157-191.

Bowers, J. (2008). Punishing the innocent. University of Pennsylvania Law Review, 156(5), 1117-1179.

Carling, A. (2017). A way to reduce indigenous overrepresentation: Prevent false guilty plea wrongful convictions. The Criminal Law Quarterly, 64(3), 415-461.

Cheng, K. K. (2013). Pressures to plead guilty: Factors affecting plea decisions in Hong Kong's magistrates' courts. The British Journal of Criminology, 53(2), 257-275. https://doi.org/10.1093/bjc/azs064

Colvin, E. (2009). Convicting the innocent: A critique of theories of wrongful convictions. Criminal Law Forum, 20(2-3), 173-192. https://doi.org/10.1007/s10609-009-9100-6

Covey, R. D. (2013). Police misconduct as a cause of wrongful convictions. Washington University Law Review, 90(4), 1133-1189.

Dervan, L. E., \& Edkins, V. A. (2013). The innocent defendant's dilemma: An innovative empirical study of plea bargaining's innocence problem. Journal of Criminal Law \& Criminology, 103(1), 1-48.

Dioso-Villa, R. (2015). A repository of wrongful convictions in Australia: First steps toward estimating prevalence and causal contributing factors. Flinders Law Journal, 17(2), 
163-202.

Doyle, J. M. (2010). Learning from error in American criminal justice. The Journal of Criminal Law and Criminology, 100(1), 109-148.

Edkins, V. A., \& Dervan, L. E. (2018). Freedom now or a future later: Pitting the lasting implications of collateral consequences against pretrial detention in decisions to plead guilty. Psychology, Public Policy, and Law, 24(2), 204-215. https://doi.org/10.1037/law0000159

Engel, C., \& Weinshall, K. (2020). Manna from heaven for judges: Judges' reaction to a quasi-random reduction in caseload. Journal of Empirical Legal Studies, 17(4), 722751.

Flynn, A. (2011). 'Fortunately we in Victoria are not in that UK situation': Australian and United Kingdom legal perspectives on plea bargaining reform. Deakin Law Review, $16(2), 361-404$.

Flynn, A., \& Fitz-Gibbon, K. (2011). Bargaining with defensive homicide: Examining Victoria's secretive plea bargaining system post-law reform. Melbourne University Law Review, 35(3), 905-932.

Flynn, A., \& Freiberg, A. (2018). Plea negotiations: Final report to the Criminology Research Council. Canberra, ACT: Criminology Research Advisory Council.

Garrett, B. (2011). Convicting the innocent: Where criminal prosecutions go wrong. Cambridge, Mass: Harvard University Press.

Gilliéron, G. (2013). The risks of summary proceedings, plea bargains, and penal orders in producing wrongful convictions in the US and Europe. In R. C. Huff \& M. Killias (Eds.), Wrongful convictions and miscarriages of justice: Causes and remedies in North American and European criminal justice systems (pp. 245-266). Routledge. https://doi.org/10.4324/9780203597286 
Gross, S. R. (2017). What we know and what we think we know about false convictions. Ohio State Journal of Criminal Law, 14(2), 753-786.

Gross, S. R., \& Shaffer, M. (2012). Exonerations in the United States, 1989 - 2012. Report by the National Registry of Exonerations.

Helm, R. K. (2019). Constrained waiver of trial rights? Incentives to plead guilty and the right to a fair trial. Journal of Law and Society, 46(3), 423-447. https://doi.org/10.1111/jols. 12169

Henderson, K. S., \& Levett, L. M. (2018). Investigating predictors of true and false guilty pleas. Law and Human Behavior, 42(5), 427-441. https://doi.org/10.1037/lhb0000297 Hennessy v Vojvodic (2010) QCA 345 (Austl.)

Huff, C. R., \& Killias, M. (Eds.). (2010). Wrongful conviction: International perspectives on miscarriages of justice. Temple University Press.

Huff, R., Rattner, A., Sagarin, E., \& MacNamara, D. E. J. (1986). Guilty until proved innocent: Wrongful conviction and public policy. Crime \& Delinquency, 32(4), 518544. https://doi.org/10.1177/0011128786032004007

Hughes, E. (2011). Innocence unmodified. North Carolina Law Review, 89(4), 1083-1124. Kellough, G., \& Wortley, S. (2002). Remand for plea: Bail decisions and plea bargaining as commensurate decisions. The British Journal of Criminology, 42(1), 186-210. https://doi.org/10.1093/bjc/42.1.186

Leo, R. A. (2005). Rethinking the study of miscarriages of justice: Developing a criminology of wrongful conviction. Journal of Contemporary Criminal Justice, 21(3), 201-223. https://doi.org/10.1177/1043986205277477

Luna, E. (2005). System failure. American Criminal Law Review, 42(4), 1201-1218.

Lysaght v Youlden (2018) WASC 38 (Austl.).

Malloy, L. C., Shulman, E. P., \& Cauffman, E. (2014). Interrogations, confessions, and guilty 
pleas among serious adolescent offenders. Law and Human Behavior, 38(2), 181-193. https://doi.org/10.1037/lhb0000065

Meissner $v R$ (1995) 184 CLR 132 (Austl.).

Ministry of Justice. (2021). Criminal court statistics quarterly, England and Wales, October to December 2020.

https://assets.publishing.service.gov.uk/government/uploads/system/uploads/attachme $\underline{\text { nt data/file/972864/ccsq bulletin_oct dec 2020.pdf }}$

Nelson v Haynes (2003) WASCA 73 (Austl.).

Nguyen v Police (2007) SASC 190 (Austl.).

Parkes, D., \& Cunliffe, E. (2015). Women and wrongful convictions: Concepts and challenges. International Journal of Law in Context, 11(3), 219-244. https://doi.org/10.1017/S1744552315000129

Peay, J., \& Player, E. (2018). Pleading guilty: Why vulnerability matters. The Modern Law Review, 81(6), 929-957. https://doi.org/10.1111/1468-2230.12374

$R v$ Davies (1993) 19 MVR 481 (Austl.).

$R v G V$ (2006) QCA 394 (Austl.).

$R v$ Wilkes (2001) NSWCCA 408 (Austl.).

$R v$ Williamson (2012) QCA 139 (Austl.).

Raymond, M. (2001). The problem with innocence. Cleveland State Law Review, 49(3), 449464.

Redlich, A. D. (2010). False confessions, false guilty pleas: Similarities and differences. In D. G. Lassiter \& C. A. Meissner (Eds.), Police interrogations and false confessions: Current research, practice, and policy recommendations (pp. 49-66). American Psychological Association. https://doi.org/10.1037/12085-003

Redlich, A. D., Bibas, S., Edkins, V. A., \& Madon, S. (2017). The psychology of defendant 
plea decision making. American Psychologist, 72(4), 339-352. https://doi.org/10.1037/a0040436

Redlich, A. D., \& Shteynberg, R. V. (2016). To plead or not to plead: A comparison of juvenile and adult true and false plea decisions. Law and Human Behavior, 40(6), 611-625. https://doi.org/10.1037//hb0000205

Redlich, A. D., Summers, A., \& Hoover, S. (2010). Self-reported false confessions and false guilty pleas among offenders with mental illness. Law and Human Behavior, 34(1), 79-90. https://doi.org/10.1007/s10979-009-9194-8

Roach Anleu, S., \& Mack, K. (2009). Intersections between in-court procedures and the production of guilty pleas. Australian \& New Zealand Journal of Criminology, 42(1), 1-23. https://doi.org/10.1375/acri.42.1.1

Roach, K. (2011). Wrongful convictions in Canada. University of Cincinnati Law Review, 80(4), 1465-1526.

Roach, K. (2015). The wrongful conviction of Indigenous people in Australia and Canada. Flinders Law Journal, 17(2), 203 - 262.

Roberts, S., \& Weathered, L. (2009). Assisting the factually innocent: The contradictions and compatibility of Innocence Projects and the Criminal Cases Review Commission. Oxford Journal of Legal Studies, 29(1), 43-70. https://doi.org/10.1093/ojls/gqn022

Sherrin, C. (2011). Guilty pleas from the innocent. Windsor Review of Legal and Social Issues, 30(1), 1-35.

United States Sentencing Commission. (2021). Overview of federal criminal cases, fiscal year 2020. Washington, DC: United States Sentencing Commission.

Vulin v Kirkman (2012) WASC 331 (Austl.).

Walker, C., \& McCartney, C. (2008). Criminal justice and miscarriages of justice in England and Wales. In R. C. Huff \& M. Killias (Eds.), Wrongful conviction: International 
perspectives on miscarriages of justice (pp. 183-212). Philadelphia, PA: Temple University Press.

Weathered, L. (2013). The growing acknowledgement of wrongful conviction: the Australian response within an international context. Victoria University Law and Justice Journal, 3(1), 79-92.

Yang, K. (2013). Public accountability of public prosecutions. Murdoch University Law Review, 20(1), 28-75.

Zhang, Y., \& Wildemuth, B. M. (2017). Qualitative analysis of content. In B. M. Wildemuth (Ed.), Applications of social research methods to questions in information and library science (pp. 318-329). Santa Barbara, CA: Libraries Unlimited.

Zottoli, T. M., Daftary-Kapur, T., Winters, G. M., \& Hogan, C. (2016). Plea discounts, time pressures, and false-guilty pleas in youth and adults who pleaded guilty to felonies in New York City. Psychology Public Policy and Law, 22(3), 250-259.

https://doi.org/10.1037/law0000095 


\section{Tables}

\section{Table 1}

The criminal offence overturned on appeal

\begin{tabular}{llc}
\hline Criminal offence & $\mathrm{n}$ & $\%$ \\
\hline Offences against government procedures, security and & 20 & 14.4 \\
operations & 18 & 12.9 \\
Acts intended to cause injury & 18 & 12.9 \\
Illicit drug offences & 16 & 11.5 \\
Traffic and vehicle regulatory offences & 12 & 8.6 \\
Sexual assault and related offences & 10 & 7.2 \\
Dangerous or negligent acts endangering persons & 7 & 5.0 \\
Theft and related offences & 7 & 5.0 \\
Weapons and explosives offences & 6 & 4.3 \\
Robbery, extortion and related offences & 6 & 4.3 \\
Fraud, deception and related offences & 5 & 3.6 \\
Unlawful entry, burglary, break and enter & 4 & 2.9 \\
Homicide and related offences & 10 & 7.2 \\
Other & & \\
\hline
\end{tabular}

Note. The offences were coded based upon the Australian and New Zealand

Standard Offence Classification. In cases that involve multiple convictions, only the most serious was coded. 


\section{Table 2}

The number of errors contributing to the guilty plea wrongful convictions and the stage of the criminal justice process the errors occurred $(n=139)$

\begin{tabular}{|c|c|c|}
\hline Variable & $\mathrm{n}$ & $\%$ \\
\hline \multicolumn{3}{|l|}{ Type of error } \\
\hline Erroneous acceptance of plea & 46 & 33.1 \\
\hline Charging error & 40 & 28.8 \\
\hline Inadequate defence representation & 38 & 27.3 \\
\hline Legal misunderstanding & 21 & 15.1 \\
\hline Mental incompetence & 14 & 10.1 \\
\hline Undue pressure & 13 & 9.4 \\
\hline Language difficulties & 7 & 5.0 \\
\hline Misleading submission & 7 & 5.0 \\
\hline Forensic error & 4 & 2.9 \\
\hline Inadequate investigation & 4 & 2.9 \\
\hline Official misconduct & 4 & 2.9 \\
\hline Identification error & 3 & 2.2 \\
\hline False confession & 3 & 2.2 \\
\hline No error & 2 & 1.4 \\
\hline Other & 8 & 5.8 \\
\hline \multicolumn{3}{|l|}{ Stage of the process } \\
\hline Police investigation & 11 & 8.1 \\
\hline Pretrial preparations & 95 & 69.9 \\
\hline Formal court procedurals & 74 & 54.4 \\
\hline
\end{tabular}

Note. Percentages add up to more than 100 as some cases involved more than one error committed during more than one stage. 


\section{Table 3}

Chi-square comparisons $(d f=2)$ of the different types of wrongful convictions by the type of errors involved and the stage of the process the errors occurred

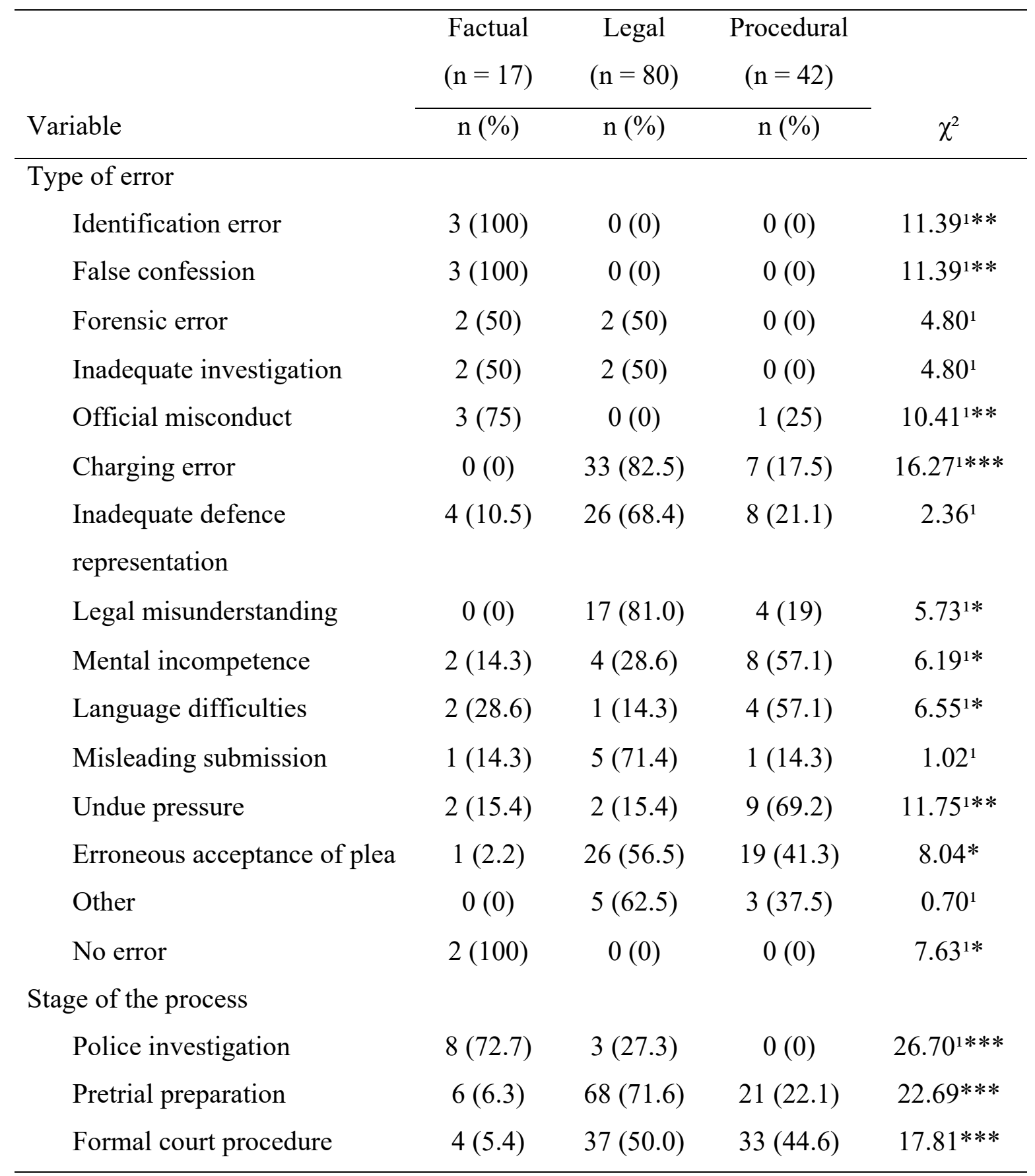

Note. ${ }^{1}$ Fisher's exact test used. ${ }^{*} \mathrm{p}<.05,{ }^{*} \mathrm{p}<.01, * * * \mathrm{p}<.001$ 


\section{Figures}

\section{Figure 1}

Total number of errors $(n=216)$ by the stage of the criminal justice process in which they occurred

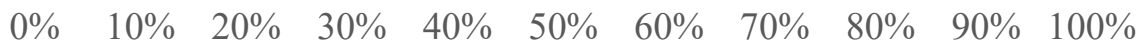
Identification error False confession Forensic error Inadequate investigation

Official misconduct

Charging error Inadequate defence representation Legal misunderstanding Mental incompetence Language difficulties Misleading submission Undue pressure

Erroneous acceptance of plea

Other

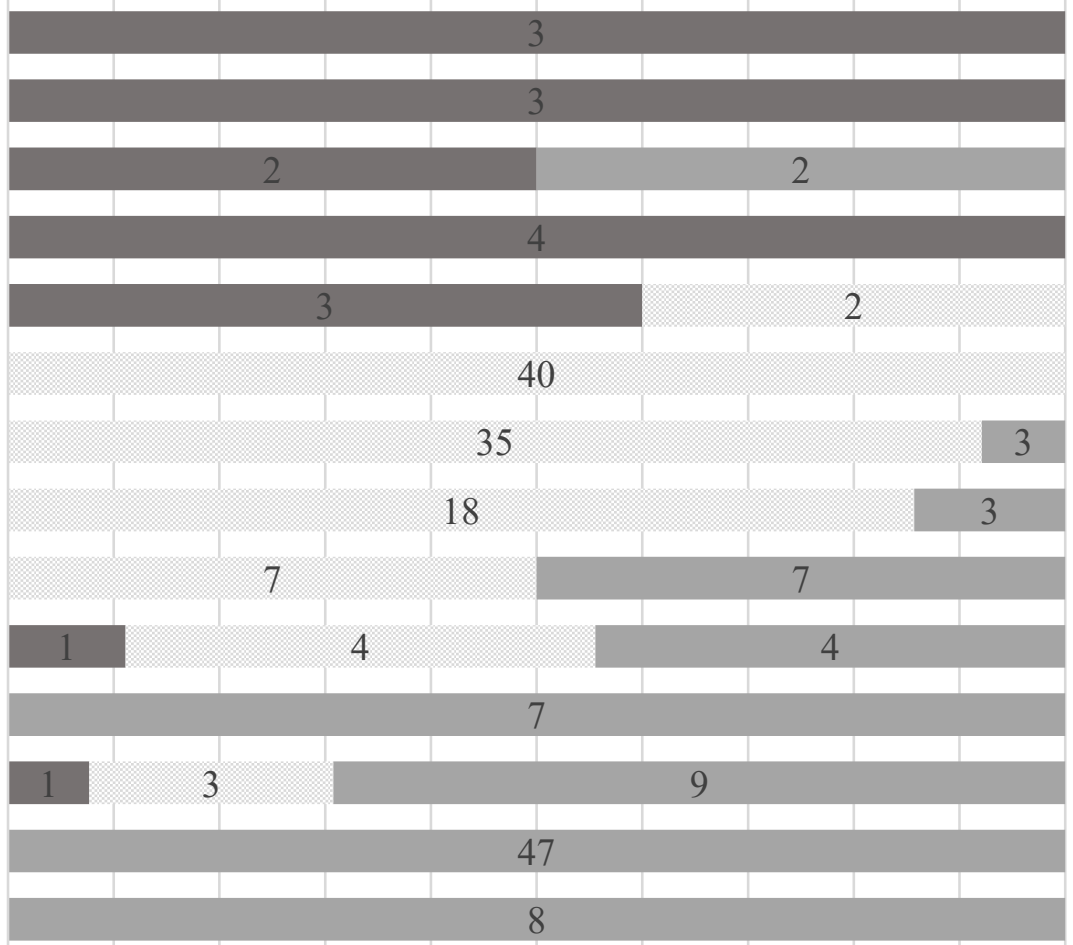

Police investigation $(\mathrm{n}=17) \approx$ Pretrial preparations $(\mathrm{n}=109) \square$ Formal court procedures $(\mathrm{n}=90)$ 